\title{
DO ENTERPRISES WHOSE COMPETITORS PARTICIPATE IN THE INFORMAL SECTOR SUFFER FROM LOWER LEVELS OF FIRM PERFORMANCE? AN EVIDENCE-BASED EVALUATION FOR THE CASE OF ALBANIA
}

\author{
Brunilda Kosta ${ }^{1}$
}

DOI: https://doi.org/10.31410/ERAZ.2019.291

\begin{abstract}
There is a wide belief that firms who operate into the informal economy negatively affect their competitors who operate in the formal economy. This paper aims to provide an evidence-based evaluation of this assumption in the context of Albania. Different official sources confirm Albanian's informal economy counts for around 40 percent of GDP. Unfair competition remains a huge obstacle of doing business. To evaluate the impact of informal competition into firms that operate fully formal, a survey is conducted using a national representative sample size of 400 firms operating in Albania, comprising all sizes and economic sectors. The linear regression analysis is employed to develop the impact analysis. The results uncovered that firms whose competitors operate into the informal economy, have lower annual sales growth rates compared with those who admit that their competitors do not engage in the informal economy. The survey results have both theoretical and practical implications which are discussed at the end of the paper.
\end{abstract}

Keywords: firm performance, informal economy, Albania.

\section{INTRODUCTION}

$\mathrm{T}$ here has been an increasingly interest of scholars to study enterprises that operate informally, meaning those who do not register and/or hide a part of sales to authorities for tax and/or labor law purposes (Siqueira et al., 2014; Ram et al., 2017; Williams et al., 2017). There are two arguments the literature highlights as motivation to study informal sector. First, there are over one half of all enterprises globally that are not registered (Acs et al., 2013), and there is a larger number that under-report their sales (Williams, 2018). Second, the informal enterprises represent a big obstacle to formal enterprises and its prevalence negatively impact the performance of formal enterprises (Lewis, 2004; Webb et al., 2013). This paper aims at examining the impact of informal entrepreneurship into the performance of firms that operate formally. The results are reporting from a survey of 400 businesses in Albania, with a representative sample. This paper provides some evidence of that enterprises admitting that their competitors engage into informal economy, are inclined to have lower annual sales growth rates compared with those admitting that those competitors do not operate informally. This provides arguments for policy makers to design effective policy measures to tackle informal economy in Albania.

This paper starts with a literature review, outlining at a glance the literature on informal sector entrepreneurship. The third section introduces the data followed up with the results. The final section closes with theoretical and policy implications. 


\section{INFORMAL SECTOR COMPETITION AND FIRM PERFORMANCE}

Theories (modernization and structuralist perspectives) highlight that formal enterprises are suffering due to the existence of unfair competition (Leal Ordóñez, 2014). In addition of the existence of business loses, governments on the other hand are losing regulatory control over work conditions (ILO, 2014) and tax revenue (Williams, 2014). Both theories emphasize that enterprises operating informally has a negative impact into the performance of enterprises that operate formally (Farrell, 2004; ILO, 2007). More specifically, the modernization theory considers informal sector competition inefficient toward formal enterprises. However, due to non-compliance with tax and/or labor authorities, informal enterprises are in advantage in terms of the price (La Porta and Shleifer, 2008). The same is accepted to be true for the structuralist perspective which depicts informal sector competitors as low-productive enterprises. However, these enterprises have low cost and so gain advantage compare with formal enterprises (Palmer, 2007). Besides all, the impact that informal enterprises have onto the performance of formal enterprises, is rarely tackled. Most of the literature on firm's performance have endeavored to study the lower productivity of informal enterprises. This poorer performance thesis has been approved by various empirical studies (Farrell, 2004; McKinsey Global Institute, 2003). When it comes to the impact of informal entrepreneurship into the firm's performance operating into formal sector, there are rare or none studies that examine this relationship. Nevertheless, there is a wide belief that formal enterprises whose competitors operate informally, have lower firm performance (Lewis, 2004; Webb et al., 2009).

To test this main hypothesis two things are essential. First, the examination of informal typologies is important in order to know how the firms could engage into informal economy. Second, the way how the firm performance is measures, should be elaborated. For the first thing, the wide literature identify at least three manners businesses could engage into informal economy: Hiding/not paying taxes, duties and/or excises (Williams, 2006), performing illicit import/ export and siphoning of VAT (VAT fraud using accounting tricks). In terms of the firm performance, a well-known measure used is the annual sales growth (Williams et al., 2017). Hence, these hypotheses seek to be tested:

H1: Formal enterprises whose competitors always/in most cases, do not pay their full taxes, have lower annual sales growth compared with enterprises whose competitors never do so.

H2: Formal enterprises whose competitors always/in most cases, engage in the illicit exporting or importing of goods, have lower annual sales growth compared with enterprises whose competitors never do so.

H3: Formal enterprises whose competitors always/in most cases, engage in VAT fraud, have lower annual sales growth compared with enterprises whose competitors never do so.

\section{DATA AND VARIABLES}

\subsection{Data}

To evaluate the hypotheses data is reported from a survey with 400 Albanian enterprises, comprising micro, small, medium and large firms and including all economic sectors. The Albanian Center for Economic Research (ACER) conducted the field work in 2015 and the author lead the 
research project. To fill the questionnaire, the field-work team used the face-to-face method. Interviews were held with Owner, Executive Director, and/or Financial Director of the enterprise, considering the typology of information the instrument required. The random selection method was chosen to pick up enterprises from the existing General Tax Directorate (GTD) data base. The stratified sampling procedure was pursued, considering two variables, size (1-4; 5-9; 10-49; 50 or more employees) and sector (Agriculture, forestry and fishing, Accommodation, Trade, Industry, Transport, Construction, Other services, Information).

\subsection{Variables}

The linear regression analysis was deployed to test the hypothesis. In this paper the annual sales growth in percentage is the dependent variable which implies the change in percentage of the current fiscal year compare with three years ago. In this paper there are three independent variables explained as below:

- Hiding/not paying taxes, duties and/or excises: a categorical variable based on the question "How often would you say are the following practices are occurring within companies/firms in your sector - that is - those that are your direct competitors? Hiding/not paying taxes, duties and/or excises". 1=never, 2=sometimes, $3=$ in most cases/always.

- Performing illicit import/export: a categorical variable based on the question "How often would you say are the following practices are occurring within companies/firms in your sector - that is - those that are your direct competitors? Performing illicit import/ export". 1=never, $2=$ sometimes, $3=$ in most cases/always.

- Siphoning" of VAT (VAT fraud using accounting tricks): a categorical variable based on the question "How often would you say are the following practices are occurring within companies/firms in your sector - that is - those that are your direct competitors? "Siphoning" of VAT (VAT fraud using accounting tricks)". 1=never, $2=$ sometimes, $3=$ in most cases/always.

Two control variables are used drawing on other studies (Williams and Horodnic, 2017a, b) described below:

- Sector: A categorical variable describing the economic sector: 1= Agriculture, forestry and fishing, 2=Accommodation, 3=Trade, 4=Industry, 5=Transport, 6=Construction, $7=$ Other services, $8=$ Information.

- Firm Age: A categorical variable describing how many years has the company been operating: $1=$ less than 5 years, $2=6-10$ years, $3=11-20$ years, $4=$ more than 20 years.

\section{FINDINGS}

The effect of informal sector competition into the firm's performance has been evaluating using the linear regression analysis which reports data from 400 firms operating in Albania. Four models which are displayed in Table 1, are used to specifically evaluate the impact of different typologies of informal sector on the firm's performance. So, Model 1 evaluates the results for the control variables (independent) to see if the firm performance varies depending on economic sector and years of experience. Model 2-4 evaluates separately the independent variables one by one. So, model 2 whether it is usual for Albanian firms not to pay all taxes, model 3 whether it is usual for Albanian firms to perform illicit import/export and model 4 whether it is usual Albanian firms to perform VAT fraud. 
Model 1 provides evidence that firm performance does not vary significantly by economic sector and years of experience. To evaluate the hypothesis that enterprises whose competitors always, or in most cases, participate in the informal sector suffer from lower levels of annual sales growth than those whose competitors never do so, model 2 displays that enterprises whose competitors always, or in most cases, do not pay their full taxes owed are more likely to suffer from lower levels of annual sales growth than those whose competitors never do so (confirming H1). Model 3 displays enterprises whose competitors always, or in most cases, engage in the illicit exporting or importing of goods are not significantly more likely to suffer from lower levels of annual sales growth than those whose competitors do not (not confirming H2) and enterprises whose competitors always or in most cases engage in VAT fraud do not suffer from lower levels of annual sales growth than those whose competitors never engage in VAT fraud (not confirming H3).

Table 1: Linear regression results

\begin{tabular}{|c|c|c|c|}
\hline Model 1 & Model 2 & Model 3 & Model 4 \\
\hline $\begin{array}{c}\text { Coefficient } \\
\text { (Standard error) }\end{array}$ & $\begin{array}{c}\text { Coefficient } \\
\text { (Standard error) }\end{array}$ & $\begin{array}{c}\text { Coefficient } \\
\text { (Standard error) }\end{array}$ & $\begin{array}{c}\text { Coefficient } \\
\text { (Standard error) }\end{array}$ \\
\hline
\end{tabular}

Sector (RC: Agriculture, forestry and fishing)

\begin{tabular}{|l|r|r|r|r|}
\hline Accommodation & $1.008(3.453)$ & $.571(3.480)$ & $-.492(3.775)$ & $-.413(3.682)$ \\
\hline Trade & $.056(3.361)$ & $.113(3.372)$ & $-.457(3.569)$ & $-.521(3.564)$ \\
\hline Industry & $-.917(3.414)$ & $-1.190(3.432)$ & $-1.652(3.628)$ & $-2.004(3.622)$ \\
\hline Transport & $.404(3.699)$ & $.106(3.725)$ & $.559(3.902)$ & $.150(3.899)$ \\
\hline Construction & $-5.961(3.775)$ & $-6.136(3.815)$ & $-3.794(4.138)$ & $-6.996(3.989) *$ \\
\hline Other services & $1.391(3.401)$ & $.699(3.436)$ & $1.614(3.695)$ & $.455(3.659)$ \\
\hline Information & $-2.391(4.892)$ & $-2.731(4.902)$ & $-2.857(5.069)$ & $-3.248(5.052)$ \\
\hline
\end{tabular}

Years of experience (RC: Less than 5 years)

\begin{tabular}{|l|r|r|r|r|}
\hline 6-10 years & $-.203(1.481)$ & $-.494(1.517)$ & $-.269(1.661)$ & $-.485(1.538)$ \\
\hline 11-20 years & $-1.689(1.399)$ & $-1.877(1.414)$ & $-2.456(1.564)$ & $-2.226(1.459)$ \\
\hline More than 20 years & $-2.128(2.081)$ & $-1.778(2.107)$ & $-2.187(2.260)$ & $-1.873(2.165)$ \\
\hline \multicolumn{5}{|l|}{} \\
\hline Hiding/not paying taxes, duties and/or excises (RC: Never) & \\
\hline Almost always/often & $-1.293(1.556)$ & \\
\hline
\end{tabular}

Performing illicit import/export (RC: Never)
\begin{tabular}{|l|l|r|r|l|}
\hline Sometimes & & & $1.360(1.691)$ & \\
\hline Almost always/often & & & $.948(1.640)$ & \\
\hline
\end{tabular}

"Siphoning" of VAT (VAT fraud using accounting tricks) (RC: Never)

\begin{tabular}{|l|r|r|r|r|}
\hline Sometimes & & & & $.039(1.463)$ \\
\hline Almost always/often & & & & $1.239(1.297)$ \\
\hline (Constant) & $3.174(3.372)$ & $5.222(3.619)$ & $3.412(3.647)$ & $3.794(3.618)$ \\
\hline Number of observations & 384 & 375 & 320 & 361 \\
\hline R2 & $\mathbf{0 . 0 3 8}$ & $\mathbf{0 . 0 4 7}$ & $\mathbf{0 . 0 3 5}$ & $\mathbf{0 . 0 4 4}$ \\
\hline
\end{tabular}

\section{DISCUSSION AND CONCLUSION}

Drawing on the data reported from 400 enterprises in Albania and the results of a linear regression analysis, it is concluded that informal sector competition negatively affects the firm performance. In other words, those companies whose competitors always, or in most cases do not pay their full taxes, are more inclined to have a lower annual sales growth. However, this does not seem to be true for all typologies of informal engagement (VAT fraud and illicit import/export).

Theoretically, these findings have implications. It confirms that unfair competition destroys the rules of the game and this is reflected into the firm performance of formal competition. 
However, this holds true for a type of informal engagement out of three stated out. In addition, this is true for Albania only. Hence, a wider representative survey in other countries should be conducted.

As a summary, this paper uncovered that informal enterprises negatively impact the firm performance of formal enterprises. This paper has the intention to foster policy makers to think about different policy approaches to effectively tackle the informal sector in Albania. If this happens, then it has achieved its aim.

\section{REFERENCES}

[1] Acs, Z, S Desai, P Stenholm and R Wuebker (2013). Institutions and the rate of formal and informal entrepreneurship across countries. Frontiers of Entrepreneurship Research, 35(15), 1-24.

[2] Farrell, D (2004). The hidden dangers of informal economy. McKinsey Quarterly, 3, 27-37

[3] ILO (2007). The Decent Work Agenda in Africa 2007-15. Geneva, ILO.

[4] ILO (2014). Transitioning from the informal to the formal economy. Report V (1), International Labor Conference, 103rd Session (2014). Geneva: ILO.

[5] La Porta, R and A Shleifer (2008). The unofficial economy and economic development. Brookings Papers on Economic Activity, 47(1), 123-35.

[6] Leal Ordóñez, JC (2014). Tax collection, the informal sector and productivity. Review of informality: Exit and exclusion. In the Theory of Economic Growth, A Lewis (1959). London: Allen and Unwin.

[7] Lewis, WW (2004). The Power of Productivity: Wealth, Poverty, and the Threat to Global Stability. Chicago: University of Chicago Press.

[8] McKinsey Global Institute (2003). Turkey: Making the Productivity and Growth Breakthrough. New York: McKinsey.

[9] Palmer, R (2007). Skills Development, the Enabling Environment and Informal Micro-enterprise in Ghana. Edinburgh: University of Edinburgh.

[10] Ram, M, P Edwards, T Jones and M Villaries-Varela (2017). From the informal economy to the meaning of informality: Developing theory on firms and their workers. International Journal of Sociology and Social Policy, 37(7/8), 361-73.

[11] Siqueira, ACO, JW Webb and GD Bruton (2014). Informal entrepreneurship and industry conditions. Entrepreneurship Theory and Practice, doi: 10.1111/etap.12115.

[12] Webb, JW, GD Bruton, L Tihanyi and RD Ireland (2013). Research on entrepreneurship in the informal economy: Framing a research agenda. Journal of Business Venturing, 28, 598-614.

[13] Webb, JW, L Tihanyi, RD Ireland and DG Sirmon (2009). You say illegal, I say legitimate: Entrepreneurship in the informal economy. Academy of Management Review, 34(3), 492-510.

[14] Williams, CC (2006). The Hidden Enterprise Culture: Entrepreneurship in the Underground Economy. Cheltenham: Edward Elgar.

[15] Williams, CC (2014) Confronting the Shadow Economy: Evaluating Tax Compliance and Behavior Policies. Cheltenham: Edward Elgar.

[16] Williams, CC (2018). Entrepreneurship in the Informal Sector: An Institutional Perspective. London: Routledge.

[17] Williams, CC and A Kedir (2017a). Starting-up unregistered and firm performance in Turkey. International Entrepreneurship and Management Journal, 13(3), 797-817. 